ljtihad: Jurnal Wacana Hukum Islam dan Kemanusiaan

Vol. 20, No. 1 (2020), pp. 23-39, doi : 10.18326/ijtihad.v20i1.23-39

\title{
Waqf fundraising through money in the industrial revolution 4.0 era: A case study on Baitulmaal Munzalan Indonesia
}

\author{
Bustami, Rio Laksamana, Zuliana Roviqoh \\ Universitas Tanjungpura Pontianak \\ E-mail:bustami_ptk@yahoo.com,rioipit89@gmail.com,zuli.anaroviqob91@gmail.com \\ DOI: 10.18326/ijtihad.v20i1.23-39
}

Only a few institutions are professionals in managing waqf in West Kalimantan Province. Baitulmaal Munzalan Indonesia Foundation (BMI) is present as one solution for people who want to donate their fund's waqf through money in the industrial revolution 4.0 era. Having only been established for three years, BMI has managed to raise funds cash waqf of Rp. 2.9 billion. This paper aims to explain the strategies and constraints faced by BMI in collecting endowment funds through money in the digital age. By using the type of field research and data collection techniques through observation, interviews, and Focus Grup Discussion (FGD), there are two research results in this paper. First, the strategies used by BMI in developing cash waqf in the digital age are companies through social media (Facebook pages and Instagram) and tablig. Kampanye through social media is the most dominant strategy used by BMI and has enormous potential. Secondly, the obstacle felt by BMI in managing and developing cash waqf is negative perceptions from the community (external obstacle). Based on the results of this study, the authors argue that marketing through social media not only has positive implications for-profit institutions but also non-profit institutions such as BMI in collecting and managing cash waqf in Indonesia.

Hanya sedikit lembaga yang secara profesional dalam pengelolaan wakaf di Provinsi Kalimantan Barat. Yayasan Baitulmaal Munzalan Indonesia (BMI) hadir sebagai salah satu solusi bagi masyarakat yang ingin menyalurkan wakaf melalui uang (wakaf tunai) di era revolusi industri 4.0. Baru berdiri selama tiga tahun, BMI telah berhasil menghimpun dana wakaf melalui uang sebesar Rp. 2.9 milyar. Tulisan ini bertujuan untuk menjelaskan strategi dan kendala-kendala yang dihadapi oleh BMI dalam menghimpun dana wakaf melalui uang di era revolusi industri 4.0. Dengan menggunakan jenis penelitian lapangan (field research) dan teknik pengumpulan data melalui observasi, wawancara dan FGD, ada dua hasil penelitian dalam tulisan ini. Pertama, strategi yang digunakan oleh BMI dalam menghimpun dana wakaf melalui uang (wakaf tunai) di era revolusi industri 4.0 adalah kampanye melalui media sosial (facebook page dan instagram) dan tablig. Kampanye melalui media sosial merupakan strategi yang 
Ijtihad: Jurnal Wacana Hukum Islam dan Kemanusiaan, Volume 20, No. 1, Juni 2020: 23-39

paling dominan yang digunakan oleh BMI dan memiliki potensi yang sangat besar. Kedua, kendala yang dirasakan oleh BMI dalam mengelola dan mengembangkan wakaf tunai adalah persepsi negatif dari masyarakat (kendala eksternal). Berdasarkan hasil penelitian ini, penulis berargumen bahwa pemasaran melalui media sosial tidak hanya berimplikasi positif terhadap lembaga profit, tetapi juga lembaga nonprofit seperti BMI dalam menghimpun dan mengelola wakaf tunai di Indonesia.

Keywords: BMI; cash waqf; fundraising; industrial revolution 4.0

\section{Introduction}

Indonesia, which is predominantly Muslim, has known the instruments of Zakat, Infaq, Sadaqah, and Waqf (Ziswaf) since before independence until now. With a majority Muslim population, the potential of Ziswaf in Indonesia is extraordinary. In the case of monetary wagf (wakaf uang) only, the annual potential is Rp. 60 trillion. This fantastic amount was obtained by Cholil Nafis (2009: 37) from the assumption that if 20 million Muslims out of 207,176,162 residents of Indonesian Muslims (Na'im, 2011: 10) would like to donate Rp. 100,000.00 every month, the endowment funds collected annually are Rp. 60 trillion. That's just the potential of monetary waqf, not to mention the types of endowments do not move and other moves in Indonesia that are so potent.

The great potential of this monetary waqf is not in line with the funds collected and the benefits felt by the Muslim community. The impact of monetary waqf funds in Islamic philanthropy has not been able to significantly minimize poverty rates in Indonesia, particularly in West Kalimantan Province. Based on data from the poor population in West Kalimantan Province in 2017-2019 (Badan Pusat Statistik, 2019), it is seen that poverty rates in West Kalimantan Province have fluctuated. In semester 2 of 2017, the poverty rate had dropped from $9.28 \%$ to $9.09 \%$, then increased again in semester 1 of 2018 to $9.16 \%$. The same situation also occurred in 2018 to 2019. The poverty rate dropped from $9.16 \%$ (semester 1 of 2018) to $8.84 \%$ (semester 2 of 2018), then rose again to $9.05 \%$ in semester 1 of 2019. The ups and downs of poverty in The West Kalimantan Province at least can show that monetary wagf instruments have not been able to significantly reduce the high poverty rate in West Kalimantan Province.

One of the factors causing the lack of exploration of potential waqf is the lack of knowledge dissemination about waqf (Muntaqo, 2015: 92), even more so these days 
increasingly sophisticated technology. Besides, there are still a few awqaf that are managed professionally and productively (Berakon and Irsad, 2017: 28). If socialization and management only use conventional methods, then waqf will be left behind and its potential cannot be explored to the full. Baitulmaal Munzalan Indonesia is present as one solution for people who want to donate their cash waqf in the industrial revolution 4.0 era.

BMI is an official Amil Zakat Institution (LAZ) established in 2017 with Baznas Decree Number: 03/BAZNAS-KB-SK/III/2018. Although classified as LAZ which is still new, BMI was able to attend by utilizing technology that developed in the era of the industrial revolution 4.0. Informally, the existence of BMI began in 2012 with the Gerakan Infaq Beras program for Islamic boarding schools and orphanages in the Pontianak City and surrounding areas. Until 2018, it is noted that BMI has accompanied more than 60 Islamic Boarding Schools and Orphanages with 3000 pupils fostered in West Kalimantan, and has branches of the Gerakan Infaq Beras in 29 major cities throughout Indonesia (Munzalan, "Tentang Kami," accessed April 23, 2019, https:/ / munzalan.id/about).

Besides, there are more creative programs from BMI by utilizing technological developments in the era of the industrial revolution 4.0. One of the programs is waqf through money (also known as cash waqf in this paper). BMI already has an unusually large income through cash waqf. The number of waqf receipts through this money can be seen based on BMI's final financial report dated 31 December 2018, amounting to Rp. 2,993,050,577.64 (BMI Financial Report dated 31 December 2018). The number of waqf through this amount of money indicates that the amount of public trust in BMI as a fundraiser and manager of cash waqf. This cannot be separated from management and programs professionally managed by BMI. Therefore, this paper is very important to study and research.

The are some studies related to cash waqf. The first mentioned in this research is a study in Malaysia. Judging from its products, Malaysia has experience in implementing creative waff products. Asmak Ab Rahman Ahmad and Wan Marhaini Wan (2011: 203) has examined the concept of waqf that is applied in insurance products. Malaysia has combined the concept of waqf with a takäful agreement and applies it to insurance products. The Takāful Malaysia Berhad Company, as a pioneer in takäful products in Malaysia, named the 
Ijtihad: Jurnal Wacana Hukum Islam dan Kemanusiaan, Volume 20, No. 1, Juni 2020: 23-39

product the Takāful-Waqf Plan. Whereas a country like Nigeria, integration of waqf into insurance products is only just a proposal contained in the results of research conducted by 'Abdulwahab Muhammad Jami'u Elesin (2017: 223). In Indonesia, there are several research results relating to the management of cash waqf, including the results of research from Qi Mangku Bahjatulloh (2015), Moch. Cholid Wardi (2016), and Khurun’in Zahro', et al. (2020).

In Malaysia, the takäful industry is developing with several methods such as mudhärabah, modified mudhärabah, wakälah-waqf, and hybrids. Because these takäful industrial products have developed quite rapidly, Apnizan Abdullah and Hakimah Yaacob (2012: 1040) then examine how to resolve the law relating to the structure and practical implementation. Malaysia has also used the Build, Operate, Transfer (BOT) contract to develop land-based wagf as a result of research conducted by Azman bin Mohd Noor and Saidatolakma BT Mohd Yunus (2014: 136).

Besides, there are several new concept proposals related to waqf products. Faizah Darus (2017: 3) in his writings offers Corporate Social Responsibility (CSR) funds given to the public that can be used through waqf instruments. Waqf from Islamic Financial Institutions (IFIs) can be used as an alternative to overcome social problems. Azniza Hartini Azrai Azaimi Ambrose (2015: 333) also believes that wagf can play a role in overcoming the debt of the Malaysian Federal Government, which is the ratio of debt to a gross domestic product of 54.47\%. Not only that, Magda Ismail Abdel Mohsin (2013: 304) argues that the potential for cash wagf is not only in the religious field, but can also finance goods and services needed globally, such as education, health, basic infrastructure, commercial activities and so on. Although creative waqf products have been implemented in Malaysia, they are not applied in all states. Based on Rahman's research results (2016: 562), only the state of Johor has implemented a waqf within a certain period.

More specifically, the results of research relating to raising cash waqf are not too many. Among these are the results of research conducted by Muhammad Sulthoni and Norma Md Saad (2018: 57). The results of the study explained that Malaysia had used a waqf fundraising model from traditional to modern to reform the waqf institutions. There are three traditional waqf fundraisers, namely istibdal, hukr, and jjäratain. While there are three 
modern waqf fund collection, namely Venture Philanthropy of Waqf Model (VPWM), ValueBased Capital Model of Waqf (VBCMW), and Social Enterprise WaqfFund Model (SEWF).

The results of research conducted by Jauhar Faradis et al (2015: 500-501) also sought to compare productive waqf collection strategies between the Selangor Waqf Comparison (PWS) of Malaysia with the Indonesian Waqf Board (BWI). The results in this paper indicate that PWS Malaysia and BWI both use two methods, namely the method of "menunggu bola" and "menjemput bola". While the difference is in the technical landscape of the two methods.

Next is an innovation based on online waqf collection services found in the research results of Irza Berakon et al (2017: 39). Berakon explained that the Government had inaugurated the Venture Wakaf Bank as an institution for collecting and managing monetary waqf in Indonesia. In raising its endowment funds, Venture Wakaf Bank uses online-based media. This waqfe-payment aims to make it easy for wäqif to conduct transactions and at the same time be able to assist Venture Waqf Banks in collecting and managing monetary waqf.

The differences in the results of previous studies with the results of the study in this paper are located in the strategy of collecting cash waqf and research subjects. Muhammad Sulthoni and Norma Md Saad revealed the models of cash waqf overflowing in Malaysia, namely istibdal, hukr, ijäratain, VPWM, VBCMW, and SEWF. Jauhar Faradis et al discussed the strategy of collecting productive waqf between PWS Malaysia and BWI who both used two methods, namely the method of "menunggu bola" and "menjemput bola". Berakon describes the service innovations undertaken by the Bank Wakaf Ventura in collecting money-based online waqf (e-payment). Whereas in this paper, the authors focus on the model of collecting waqf funds through money in the industrial revolution 4.0 era conducted by BMI.

The background above and the position of this paper differs from some of the results of previous studies. There are two problem statements discussed in this paper. First, what strategies are used by BMI in raising waqf funds through money? Second, what the obstacles are faced by BMI in raising waqf funds through money in the industrial revolution 4.0 era. The purpose of this study is to describe and analyze the strategies and constraints faced by BMI in raising waqf funds through money in the industrial revolution 4.0 era. 
Ijtihad: Jurnal Wacana Hukum Islam dan Kemanusiaan, Volume 20, No. 1, Juni 2020: 23-39

\section{Research method}

This paper uses field research. Facts and field data referred to in this study are directly taken from the BMI Foundation having its address at Jalan Sui Raya Dalam Gang Imaduddin Number 4, Sui Raya District, Kubu Raya Regency, West Kalimantan Province. There are four data collection techniques in this paper, namely observation, interviews, documentation, and Focus Group Discussion (FGD). After the data is collected, the authors analyze it with qualitative data analysis.

This research focuses on the strategy of raising waqf funds through money at Indonesian migrant workers in the industrial revolution 4.0 era. The influence of the industrial revolution 4.0 is indeed very large. His achievements in manufacturing are synonymous with the realization of smart factories and smart production. Not only in manufacturing, but the industrial revolution 4.0 also influences in all sectors such as health, education, trade, tourism, transportation, construction, finance, and so on. The beneficiary of this change is not the system, but the users of the system (Chou, 2019: 111). This is what BMI tries to use to raise waqf funds through money.

\section{Waqf fundraising strategy through money}

There are two strategies used by BMI to raise waqf through money, namely campaigns through social media and tabliq (The results of interviews with the Director of BMI, M. Imam Muttaqin, on 22 August 2019). Between the two types of strategies, campaigns through social media are the most dominant strategies used by BMI and have enormous potential compared to the tabliq strategy. That's because people now use social media more than others. Muttaqin believes that people are more familiar with their cellphones (social media) than their neighbors. Therefore, online media is very influential in preaching today, as well as at BMI.

Social behavior is the impact of changing times and places in the era of the industrial revolution 4.0 (Hakim, 2014: 59). Religious institutions such as BMI must be able to respond to these changes. For more details about the two waqf fundraising strategies through money used by BMI, the author can explain as follows: 


\section{Campaign through Social Media}

Social Media is a two-way communication through writing, photos, audio, and video that is channeled through the internet (Riese, 2010: 1). There are 130 million Indonesians who use social media. The most commonly used social media by Indonesians based on the highest users in January 2018 are YouTube 43\%, Facebook 41\%, WhatsApp 40\%, Instagram 38\%, Line 33\%, BBM 28\%, Twitter 27\%, Google+ 25\%, FB Messenger 24\%, LinkedIn 16\%, Skype 15\%, and WeChat 14\% (130 Juta Orang Indonesia Tercatat Aktif di Media sosial, Agustus 2019, https://inet.detik.com/cyberlife/d-3912429/130-juta-orang-indonesiatercatat-aktif-di-Media sosial).

The number of users of social media in Indonesia today is well utilized by the marketing world. Marketers are starting to use social media as one of their marketing strategies, including BMI in this paper. One proof of marketing through social media can increase considerably is the business of Remote and Medium Enterprises (SMEs) in India. Besides, the results of research conducted by Sheshadri Chatterjee and Arpan Kumar Kar (2020: 1) of $310 \mathrm{SME}$ companies also stated that there are benefits, ease of use and positive compatibility in social media felt by SMEs. The results of this study strengthen previous research which states that social media has an impact on SME businesses. Not only in India but almost all over the world. The impact obtained from social media is mostly related to customers, business partners, competitors, and stakeholders (Wardati and Er, 2019: 976).

The results of research from Shih-Chih Chen and Chieh-Peng Lin (2019: 22) also show other advantages of social media over marketing activities. The article explained that marketing activities through social media indirectly affect user satisfaction through social identification and perceived value. At the same time, social identification and perceived value directly affect user satisfaction by influencing purchase intention, participation, and sustainability. The results of the study are the results of a survey of 502 social media users.

Some potential and convenience in social media are also put to good use by BMI as a community empowerment agency engaged in the Ziswaf field. Promotions or campaigns through social media are used by BMI in waqf fundraising strategies through money. Muttaqin even emphasized that campaigning through social media is the most dominant strategy used by BMI and has enormous potential and promises when compared to other strategies. 
ljtihad: Jurnal Wacana Hukum Islam dan Kemanusiaan, Volume 20, No. 1, Juni 2020: 23-39

Before campaigning waqf through money using social media, BMI first planned the object to be used for wagf through the money. After the object is determined and the amount of funds needed has been budgeted, then BMI campaigns or promotes to the Muslim community through social and oral media. Waqf funds through money collected, then used to buy materials used to build waqf-based infrastructure. The infrastructure that is built from wagf funds through the money is infrastructure managed by BMI and other propaganda infrastructure affiliated with BMI, and can also be used to renovate offices and its kind.

There are two social media that are often used by BMI in campaigning for cash waqf, namely Facebook and Instagram. The address for campaigning for cash waqf on Facebook Page can be accessed on the Gerakan Wakaf Produktif and Instagram on @ munzalan.id to find out more about the information and content that has been disseminated in the BMI social media account. In addition, BMI also uses social media in the form of WhatsApp to follow up on all the information and content. The social media in the form of WhatsApp is used as customer service with contact numbers 081381295252 and 081254903375.

Picture 1. Example of $W a q f$ Content through Money on Instagram
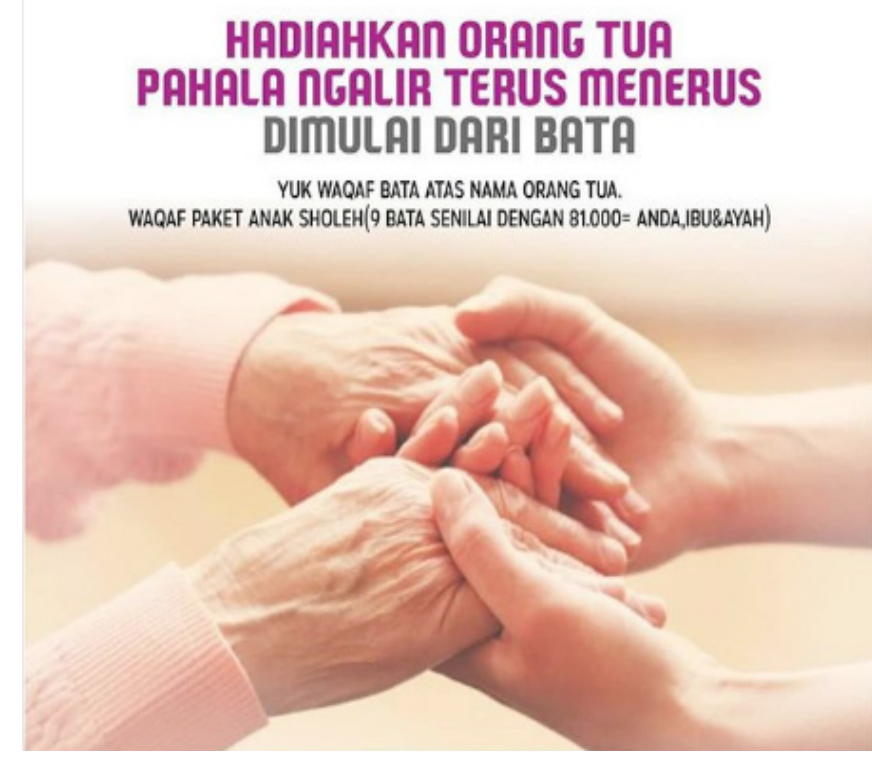

Source: @munzalan.id (21 August 2019) 
One of the contents is the waqf campaign through money through the need for bricks to build Munzalan Tower. The content can be seen in the image above. The price of one brick is Rp. 9,000. BMI made a 9 brick package content of Rp. 81,000. Waqf through money collected through campaigns through social media is then spent to buy building materials or tools, in this case, is brick. If building materials or tools are available, BMI continues to develop wagf-based infrastructure through this money.

The strategy undertaken by BMI is not only conducting campaigns through social media or interested Muslim communities that can come directly at the BMI Office. However, BMI preserves and maintains data that has been entered to be followed up for each boasting. Muttaqin (The results of interviews with the Director of BMI, M. Imam Muttaqin, on 22 August 2019) argues that a lot of good people out there need to be reminded to do good because several factors include their busyness.

This strategy of using social media does not only cover Pontianak City but throughout Indonesia and there are also BMI donors from abroad (Results of an interview with one of BMI's online Customer Service (CS) at the BMI Office on 22 August 2019). In addition to being online through social media, BMI also provides CS offline at the BMI Office located at Jalan Sui Raya Dalam Gang Imaduddin Number 4, Sui Raya District, Kubu Raya Regency, West Kalimantan Province. The aim is to provide information about products owned by BMI.

At this time, BMI is currently having an infrastructure project through wagf funds through money to build a Mosque-Based Educational Institution (LPBM) or Munzalan Tower. The funds needed to build the six levels of the LPBM are 12 billion (The results of interviews with the Director of BMI, M. Imam Muttaqin, on 22 August 2019). The method is BMI informs its Facebook Page and Instagram accounts about the need for raw materials used in the project.

In contrast to BMI, Lazis of the Great Mosque of Syuhada Yogyakarta can manage its waqf for matters that are productive and provide great benefits to the surrounding community. The flagship program is called Pumukiman Ternak Mandiri (PTM). The number of goats produced from this program in Gunungkidul reached 20 goats in 2017, PTM Cangkringan produced 14 sheep in 2015, PTM Tepus produced 10 goats in 2016 to 
Ijtihad: Jurnal Wacana Hukum Islam dan Kemanusiaan, Volume 20, No. 1, Juni 2020: 23-39

20 goats in 2017, and PTM Pundong produced 22 goats in 2016 (Oktarina and Asnaini, 2018: 121-22).

\section{Tablig}

On the website https:/ / kbbi.web.id/tablig accessed on August 29, 2019, the word "tablig" is etymologically meaningful 'broadcasting Islamic teachings' and 'delivery.' In terminology, Moh. Ali Aziz (2012: 20) defines tabliq is one part of the Islamic da'wah system by conveying and broadcasting Islamic messages carried out by individuals and groups verbally and in writing. Meanwhile, according to Muhiddin (2002: 63), tabliq is an effort to convey the teachings of God to His servants by informing, spreading and teaching His teachings to others to enlighten the mind and soothe the conscience.

Tablig is one of the four characteristics of the prophet, besides being honest (siddiq), responsible (amānah), and intelligent (fatānah). These four characters must be emulated by every Muslim to improve themselves in behavior (Huda and Ispriyarso, 2019: 161). The legal basis for this tablig is contained in the word of Allah in Surah Al-Maidah verse 67 as follows:

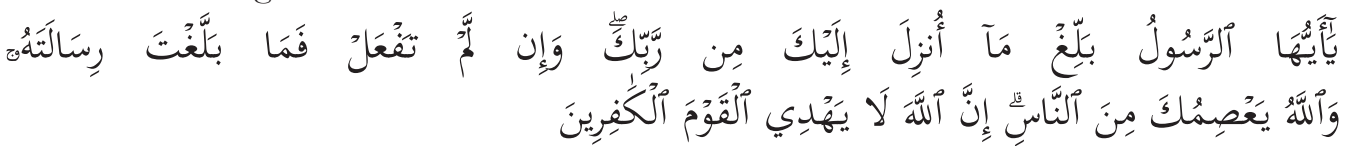

"O Messenger! Deliver what has been revealed to you from your Lord; and if you do it not, then you have not delivered His message, and Allah will protect you from the people; surely Allah will not guide the unbelieving people." (Q.S. Al-Maidah [5]: 67)

The above verse according to Sayyid Quthub, as quoted by Baharuddin Ali (2014: 128), is intended for the Prophet Muhammad in connection with the book expert. In this verse, Allah commanded the Prophet Muhammad to carry out the tablig as well as possible. In addition to the Messenger of Allah, the tablig's orders were also charged to his people according to their respective abilities. This is as the hadith of the Prophet Muhammad who reads:

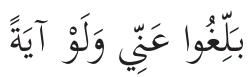

"Convey from me, even though one verse." (HR. Bukhari No. 3461)

Tablig obligation is practiced by BMI as a community empowerment organization engaged in the Ziswaf field and is used as one of the strategies in developing cash waqf. 
This is based on the results of researchers' interviews with the Managing Director of BMI, M. Imam Muttaqin. Muttaqin explained that when the BMI held various events, seminars, FGDs, private courses, training, recitation, and its kind, at the end of the session, the BMI usually told the congregation to set aside their assets to be presented to the BMI whose results could be used for benefit people (Hakim, 2016: 2).

There is some BMI management who become resource persons or mentors in various activities held by BMI. Among them were Ustaz Luqmanulhakim (Head of Munzalan Ashabul Yamin Islamic Boarding School and Poor Impossible Book Author), Adi Prataman Larisindo (Head of Munzalan Ashabul Yamin Islamic Boarding School), Ustaz Nur Hasan, and M. Imam Muttaqin (Managing Director of BMI). After delivering the material, the resource persons conveyed and socialized the Gerakan Wakaf Produktif program in the form of waqf through money to their congregation at the end of the session.

The influence of these religious leaders in calling for or giving advice (tabliq) to the community to make donations as their assets (in this case is cash waqf) is very influential in raising waqf funds managed by BMI. Besides, BMI also utilizes and endorses artists and religious figures at the national level. There are several artists and religious figures who have been endorsed by BMI, namely Ifan (Band Vocalist Seventeen), Rizal (Band Vocalist Armada), Arie Untung and Fenita Arie (his wife), Ayah Kembar, Hanan Attaki who are familiar in millennial circles, and Ustaz Adi Hidayat Lc., MA. (The results of interviews with the Director of BMI, M. Imam Muttaqin, on 22 August 2019).

\section{The constraints in raising waqf funds through money}

There are no internal obstacles experienced by BMI in raising endowment funds through money. There is only one external obstacle experienced by BMI, namely negative perceptions from the community. The constraints referred to here are all things that can limit the system in achieving organizational or corporate goals (Larasati dan Haksama, 2016: 155). Furthermore, Hansen and Mowen (2007) in Selviana Putri Larasati and Setya Haksama (2016: 157) divided the constraints based on their origin into two types, namely internal and external constraints. First is internal constraints, namely the factors contained in the organization that can limit the performance of the organization. These internal constraints 
Ijtihad: Jurnal Wacana Hukum Islam dan Kemanusiaan, Volume 20, No. 1, Juni 2020: 23-39

must be optimally utilized by organizations to increase output to the maximum extent possible without increasing inventory and operational costs. Second is external constraints, namely factors that are outside the organization that can limit organizational performance.

These constraints are also experienced by BMI as a community empowerment agency engaged in the Ziswaf field. In general, there are no internal obstacles felt by BMI in managing and developing cash waqf. This is because the waqf instrument is believed to be related not only to world affairs but also to the hereafter. So far, BMI has experienced in building infrastructure projects based on waqf which has always been provided with the ease in the funds needed. The amount of funds needed by BMI to build a waqf-based infrastructure project is always accompanied by a generous amount of waqf. In fact, cash waqf received by BMI can reach 100 million rupiahs every month.

This is as stated by Muttaqin, "Secara prinsip, ketika kita membangun sesuatu kita mempunyai proyeksi. Proyeksi dana terkumpul, proyek wakaf sambil jalan. Dunia Ziswaf ini berbicara dengan hal-hal yang gaib. Ketika kebutuhan ada, biasaya wäkifnya juga banyak. Rata-rata dana wakaf yang masuk di sini dalam satu bulan di atas 100 juta. Artinya, tingkat kemampuan penyerapan dana untuk. pembangunan untuk wakaf yang masuk masib bisa sustainable dengan dana wakaf yang diperoleb" (The results of interviews with the Director of BMI, M. Imam Muttaqin, on 22 August 2019).

Based on the final financial statements of BMI, the amount of wagf through money at BMI dated 31 December 2018 was Rp. 2,993,050,577.64. While waqf through the money that has been distributed is Rp. 535,414,900 (BMI Financial Report dated 31 December 2018). The amount of waqf through this much money indicates that the amount of public trust in BMI as a cash waqf collector and manager. This cannot be separated from management and programs professionally managed by BMI.

The more challenging obstacle by BMI in managing and developing cash waqf is external constraints. According to Muttaqin (The results of interviews with the Director of BMI, M. Imam Muttaqin, on 22 August 2019), the external constraints experienced by BMI in managing and developing cash waqf are negative perceptions from the community. There are so many negative opinions from the public about the use and utilization of the cash waqf. Starting from the use of the six levels of the LPBM building and its use. There is even a former BMI administrator who believes that the Ziswaf funds managed by BMI are 
mixed between community and business funds (Equator, "Mantan Pengurus Munzalan Angkat Bicara Dana Umat dan Bisnis Campur Aduk," t.t., https://equator.co.id/mantanpengurus-munzalan-angkat-bicara-dana-umat-dan-bisnis-campur-aduk/). In fact, BMI always tries to do transparency by documenting its financial reports, both monthly and annual financial reports.

Associated with the benefits that will be felt by the community with the Munzalan Tower which was built with approximately 12 billion funds is the existence of a missionary movement in the form of mosque-based educational institutions. Inside the waqf-based building, there will be a teaching-learning process, training, seminars, and the like and all these activities will be carried out free of charge. The way to do this is to collaborate on zakat, infaq, sedekah, and waqf obtained such as the Rumah Santri Munzalan. The Rumah Santri Munzalan building uses waqf through money. Santri can stay free of charge. Cash waqf funds are used to build the place and renovate it. While the infaq, sedekah, and zakat can be used to finance other needs.

\section{Conclusion}

Based on the discussion described earlier, there are two research results in this paper. First, the strategies used by BMI in raising waqf funds through money (cash waqf) in the industrial revolution 4.0 era are campaigns through social media (Facebook Page and Instagram) and tabliq. Campaign through social media is the most dominant strategy used by BMI and has enormous potential. Second, the obstacle felt by BMI in managing and developing waqf through money is a negative perception from the community (external constraints).

The authors' recommendation to overcome obstacles in the form of negative perceptions from the community is to increase accountability and transparency in collecting, managing, and utilizing waqf through the money in detail and periodically (monthly and annually). The results are then published on BMI's website and social media. In addition, as a professional institution in managing waqf property, BMI can also work together with the Head of the Kantor Urusan Agama (KUA) and the Lembaga Keuangan Syariah Penerima Wakaf Uang (LKS-PWU) as Pejabat Pembuat Akta Ikrar Wakaf (PPAIW) in the collection cash waqf and monetary waqf as mandated by Law Number 41 of 2004 concerning Waqf. 
ljtihad: Jurnal Wacana Hukum Islam dan Kemanusiaan, Volume 20, No. 1, Juni 2020: 23-39

The results in this study offer a waqf fundraising model through money in the industrial revolution 4.0 era. Social media that are used by the majority of the Muslim population in Indonesia, can not only be used as a medium for establishing a friendship, getting information and conducting buying and selling transactions but can also be used in religious activities. Therefore, the authors argue that marketing through social media not only has positive implications for for-profit institutions but also non-profit institutions such as BMI in collecting and managing cash waqf in Indonesia.

\section{Bibliography}

130 Juta Orang Indonesia Tercatat Aktif di Media sosial. 26 August 2019, https://inet.detik. com/cyberlife/d-3912429/130-juta-orang-indonesia-tercatat-aktif-di-Media sosial.

Abdullah, Apnizan, and Hakimah Yaacob. "Legal and Shariah Issues in the Application of Wakalah-Waqf Model in Takaful Industry: An Analysis." Procedia - Social and Behavioral Sciences, vol. 65, December 2012, pp. 1040-45. DOI.org (Crossref), doi:10.1016/j. sbspro.2012.11.239.

Ahmad, Asmak Ab Rahman and Wan Marhaini Wan. "The Concept of 'Waqf and its Application in an Islamic Insurance Product: The Malaysian Experience." Arab Law Quarterly, vol. 25, no. 2, 2011, pp. 203-19, doi:10.1163/157302511X553994.

Ali, Baharuddin. “Tugas dan Fungsi Dakwah dalam Pemikiran Sayyid Quthub." Jurnal Dakwah Tabligh, vol. 15, no. 1, 2014.

Ambrose, Azniza Hartini Azrai Azaimi, et al. "The Possible Role of Waqf in Ensuring a Sustainable Malaysian Federal Government Debt." Procedia Economics and Finance, vol. 31, 2015, pp. 333-45. DOI.org (Crossref), doi:10.1016/S2212-5671(15)01205-8.

Aziz, Moh. Ali. Edisi Revisi Ilmu Dakwah. Prenada Media Group, 2012.

Badan Pusat Statistik. Persentase Penduduk Miskin Menurut Provinsi 2007-2019. https://www. bps.go.id/dynamictable/2016/08/18/1219/persentase-penduduk-miskin-menurutprovinsi-2007---2019.html. Accessed 16 April 2020.

Bahjatulloh, Qi Mangku. "Pengembangan Wakaf Tunai Berbasis Umrah di Pondok Pesantren Ta'mirul Islam Surakarta.” Inferensi Jurnal Penelitian Sosial Keagamaan, vol. 9, no. 1, 2015, pp. 137-58, doi:10.18326/infs13.v9i1.137-158. 
Berakon, Izra, and Agus Muhammad Irsad. "E-Payment: Inovasi Layanan Penghimpunan dan Redistribusi Wakaf Uang Berbasis Online dalam Percepatan Pembangunan Ekonomi Indonesia." Jurnal Al-Qardh, vol. 2, no. 1, June 2017, pp. 26-41. DOI.org (Crossref), doi:10.23971/jaq.v2i1.824.

BMI Financial Report Dated 31 December 2018.

Chatterjee, Sheshadri, and Arpan Kumar Kar. "Why Do Small and Medium Enterprises Use Social Media Marketing and What Is the Impact: Empirical Insights from India." International Journal of Information Management, vol. 53, August 2020, pp. 102103. DOI. $\operatorname{org}$ (Crossref), doi:10.1016/j.ijinfomgt.2020.102103.

Chen, Shih-Chih, and Chieh-Peng Lin. "Understanding the Effect of Social Media Marketing Activities: The Mediation of Social Identification, Perceived Value, and Satisfaction." Technological Forecasting and Social Change, vol. 140, March 2019, pp. 22-32. DOI.org (Crossref), doi:10.1016/j.techfore.2018.11.025.

Chou, Shuo-Yan. "The Fourth Industrial Revolution: Digital Fusion with Internet of Things." Journal of International Affairs, vol. 72, no. 1, 2019, pp. 107-20.

Darus, F., Ahmad Shukri, N. H. ,. Yusoff, H. ,. Ramli, A. ,. Mohamed Zain, M. ,. \&. Abu Bakar, N. A. "Empowering Social Responsibility of Islamic Organizations Through Waqf." Research in International Business and Finance, vol. 42, 2017, pp. 959-965. Zotero, doi:10.1016/j.ribaf.2017.07.030.

Elesin, 'Abdulwahāb Muhammad Jāmi’u. “The Role of Al-Awqāf (Islamic Endowments) in Poverty Alleviation and Community Development in the Nigerian Context." Journal of Muslim Minority Affairs, vol. 37, no. 2, April 2017, pp. 223-32. DOI.org (Crossref), do i:10.1080/13602004.2017.1339497.

Equator. Mantan Pengurus Munzalan Angkat Bicara Dana Umat dan Bisnis Campur Aduk. https:/ / equator.co.id/mantan-pengurus-munzalan-angkat-bicara-dana-umat-danbisnis-campur-aduk/.

Faradis, Jauhar, et al. "Manajemen Fundraising Wakaf Produktif: Perbandingan Wakaf Selangor (PWS) Malaysia dan Badan Wakaf Indonesia." Asy-Syir'ah: Jurnal Ilmu Syariah dan Hukum, vol. 49, no. 2, 2015. Zotero, doi:10.14421/asy-syir'ah.2015.\%25x. 
Ijtihad: Jurnal Wacana Hukum Islam dan Kemanusiaan, Volume 20, No. 1, Juni 2020: 23-39

Hakim, Muhammad Lutfi. "Pergeseran Paradigma Maqasid Al-Syari'ah: Dari Klasik sampai Kontemporer." Al-Manahij: Jurnal Kajian Hukum Islam, vol. 10, no. 1, February 2017, pp. 1-16. DOI.org (Crossref), doi:10.24090/mnh.v10i1.913.

---. "Rekonstruksi Hak Ijbar Wali (Aplikasi Teori Perubahan Hukum dan Sosial Ibn alQayyim Al-Jawziyyah)." Al-Manabij: Jurnal Kajian Hukum Islam, vol. 8, no. 1, 2014, pp. 45-62. DOI.org (Crossref), doi:https://doi.org/10.24090/mnh.v8i1.401.

Huda, Muhammad Chairul, and Budi Ispriyarso. "Contribution of Islamic Law in the Discretionary Scheme That Has Implications for Corruption.” Ijtihad: Jurnal Wacana Hukum Islam Dan Kemanusiaan, vol. 19, no. 2, December 2019, pp. 147-67. DOI.org (Crossref), doi:10.18326/ijtihad.v19i2.147-167.

Larasati, Selviana Putri \&. Setya Haksama. "Penerapan Theory of Constraint pada Kepuasan Kerja Karyawan Rumah Sakit Mata Undaan Surabaya." Jurnal Administrasi Kesehatan Indonesia, vol. 4, no. 2, 2016.

Mohsin, Magda Ismail Abdel. "Financing through Cash-Waqf: A Revitalization to FInance Different Needs." International Journal of Islamic and Middle Eastern Finance and Management, vol. 6, no. 4, pp. 304-321. Zotero, doi:10.1108/imefm-08-2013-0094.

Muhiddin. Dakwah dalam Perspektif Al Qur'an. Pustaka Setia, 2002.

Muntaqo, Firman. "Problematika dan Prospek Wakaf Produktif di Indonesia." Al-Abkam, vol. 1, no. 25, April 2015, DOI.org (Crossref), doi:10.21580/ahkam.2015.1.25.195.

Munzalan. Tentang Kami. munzalan: https://munzalan.id/about. Accessed 23 April 2019.

Nafis, Cholil. "Wakaf Uang Untuk Jaminan Sosial.” Jurnal Al-Awqaf, vol. 2, no. 2, 2009.

Na'im, Akhsan and Hendry Syaputra. Kewarganegaraan, Suku Bangsa, Agama, dan Bahasa Sehari-Hari Penduduk Indonesia Hasil Sensus Penduduk 2010. Badan Pusat Statistik, 2011. Noor, Azman bin Mohd, and Saidatolakma bt Mohd Yunus. "Application of the Build, Operate, Transfer (Bot) Contract as a Means of Financing Development of Waqf Land: Malaysian Experience.” Arab Law Quarterly, vol. 28, no. 2, July 2014, pp. 13657. DOI.org (Crossref), doi:10.1163/15730255-12341281.

Oktarina, Amimah, and Asnaini Asnaini. "Developing Models of Productive Waqf Masjid Agung Syuhada Yogyakarta.” QIJIS (Qudus International Journal of Islamic Studies), vol. 6, no. 1, July 2018, pp. 103. DOI.org (Crossref), doi:10.21043/ qijis.v6i1.3719. 
Rahman, Muhamad Firdaus Ab. \&. Muhammad Amanullah. "Ta'bīd al-Waqf wa Ta'qītuhu fị Wilāyāt Mukhtārah fì Malaysia." Studia Islamika, vol. 23, no. 3, 2016, pp. 561-603, doi:10.15408/sdi.v23i3.3592.

Results of an interview with one of BMI's online Customer Service (CS) at the BMI Office on 22 August 2019.

Riese, M., Pennisi, L. ,. \&. Major, A. Using Social Media to Market Your Business. Nebraska Lincoln, 2010.

Sulthoni, Muhammad, and Norma Md Saad. "WaqfFundraising Management: A Conceptual Comparison between Traditional and Modern Methods in the Waqf Institutions." Indonesian Journal of Islam and Muslim Societies, vol. 8, no. 1, July 2018, pp. 57. DOI.org (Crossref), doi:10.18326/ijims.v8i1.57-86.

The results of interviews with the Director of BMI, M. Imam Muttaqin, on 22 August 2019.

Wardati, Nanda Kurnia, and Mahendrawathi Er. "The Impact of Social Media Usage on the Sales Process in Small and Medium Enterprises (SMEs): A Systematic Literature Review." Procedia Computer Science, vol. 161, 2019, pp. 976-83. DOI.org (Crossref), doi:10.1016/j.procs.2019.11.207.

Wardi, Moch. Cholid. "The Implementation of Cash Waqf in the Pesantren of Al-Amien Prenduan Sumenep Regency of Madura." Al Ibkam: Jurnal Hukum \& Pranata Sosial, vol. 11, no. 1, 2016, pp. 93-119, doi:10.19105/al-ihkam.v11i1.860.

Zahro', Khurun'in et al. "Implementasi Pendistribusian Wakaf Tunai Sebagai Penunjang Usaha Kecil Menengah di Badan Wakaf Uang \& Badan Wakaf Tunai MUI Yogyakarta." Ulul Albab: Jurnal Studi dan Penelitian Hukum Islam, vol. 3, no. 1, 2020, pp. 49-66, doi:10.30659/jua.v3i1.7554. 
